\title{
Lion in Winter: Sam Steele, the Yukon, and the Chaos in the Canadian Expeditionary Force in England
}

\author{
William F. Stewart \\ Independent Historian
}

\begin{abstract}
Major-General Sir Samuel Benfield Steele, the iconic Western Canadian police officer famed for helping to tame the West and the rowdy miners of the Yukon, was also a senior military commander in the chaotic administration of the Canadian Expeditionary Force in England in the First World War. Called the "Lion of the Frontier," by one biographer, Steele was less successful in his First World War command than popular narratives of his life have portrayed. This article demonstrates how he floundered under the strains of total war. In the Yukon, Steele's natural decisiveness and independence received free rein, where he did not have to defer and get approval from multiple authorities for decisions, and where the scale of his responsibility was such that he could directly interact with all involved. In those conditions, Steele thrived. He was a leader made by the frontier and performed best in that environment. In England, now in the centre and far from the frontier, the attributes, character, and experience that served him so well did not translate. Steele was not the primary culprit or cause of the chaos in the administration in England, but neither was he blameless or innocent of contributing to it. In effect, the Lion of the Frontier became the Lion in Winter. This article is part of a special collection of papers originally presented at a conference on "The North and the First World War," held May 2016 in Whitehorse, Yukon.
\end{abstract}

The Northern Review 44 (2017): 267-291 
[Steele was] feared and respected by men who as a usual thing feared neither God or man (NWMP Constable ${ }^{1}$ )

As General Officer Commanding, Troops, Shoncliffe Command, under which all Canadian Troops in this area come, I contend that I must not be passed over and ignored in the way I have been as is the case under review. (Steele to Carson, 14 Nov 1916²)

Major-General Sir Samuel Benfield Steele, KCMG, CB, MVO, the iconic Western Canadian police officer famed for helping to tame the West and the rowdy miners of the Yukon, was also a senior military commander in the chaotic administration of the Canadian Expeditionary Force (CEF) in England in the First World War. Steele, whom one biographer called the "Lion of the Frontier," commanded the North-West Mounted Police (NWMP) in the Yukon and British Columbia at the height of the Klondike Gold Rush and was the embodiment of vigorous Canadian, Victorian-era masculinity. ${ }^{3} \mathrm{He}$ won further renown for commanding Lord Strathcona's Horse in the Second Anglo-Boer War, and as a division commander in the South African Constabulary. During the First World War, Steele was the General Officer Commanding (GOC) Canadians, as well as the British area command that included the main Canadian training base at Shorncliffe, England. But he was less successful in this command than popular narratives of his life have portrayed. He was one of six competing Canadian authorities in the hydra-headed organization of the CEF in England. The strengths and lessons that served him well on the frontier were of less value in the larger-scale and more constrained environment of the CEF in England. Canadian Corps and British officers made repeated and vociferous complaints about the quantity and quality of replacements produced by Steele's command. Unlike the Canadian Corps that progressively improved, the CEF's administration in England did not. Steele played a role in this chaos, and this will be analyzed here.

This article will examine this dichotomy in results between Steele's accomplishments on the frontier and his far more modest performance when operating in the metropole. It begins with a brief description of Steele and his career to 1898; then discusses his time in the Yukon, the reasons for his success, and his post-Yukon military career; and then will position him in the anarchic administrative situation of the CEF. It will highlight how weak Canadian leadership in England contributed to an ineffective and inefficient organization with deleterious effects on the forces in the 
field. The article will show how Steele, a product of the frontier, was miscast as a commander of training formations in the heartland in a war he did not understand.

While there are many popular biographies of Steele, and he often appears in monographs, there is no full scholarly biography, despite his prominence and importance. ${ }^{4}$ Rod Macleod's entry in the Dictionary of Canadian Biography is the most balanced, albeit necessarily short, account of his life. ${ }^{5}$ Robert Stewart's Lion of the Frontier is the most detailed and researched biography, but relies heavily and uncritically on Steele's own writing. The other popular biographies are based on secondary sources and are not analytical. ${ }^{6}$ All of these biographies are focused on his Mounted Police career, as to be expected, and give only cursory attention to his military period as a coda to his more important earlier endeavours. Further, not having delved into the CEF archives for documents beyond those written by Steele, biographers such as Robert Stewart unquestionably accept his perspective. For instance, Steele falsely claimed to have instituted the policy of sending reinforcements to battalions based on regions. ${ }^{7}$ As a result, the bare facts of his military career are presented uncritically or with a sense that the Canadian authorities treated him unfairly. Steele's autobiography, Forty Years in Canada, ends before the start of the First World War and like all such works has to be carefully interpreted for what it does and does not say. ${ }^{8}$ Steele was sensitive about his reputation and wanted to shape it to his liking. ${ }^{9}$ A more in-depth examination of this period provides a new and more balanced perspective on this aspect of Steele's career.

\section{Description}

Steele was tall, muscular, handsome, and rugged, and he thrived in the frontier conditions of the Canadian West and North. As his biographer expressed it, he "was everyone an idealistic old-fashioned Canadian would want to be ...." Steele was a man shaped and conditioned by the frontier just as he shaped it, and the effects continue to this day in the West. ${ }^{10}$ He had prodigious stamina, dedication, and appetite for work. He was a strong leader and he did not brook with outside criticism of his troops, which endeared him to them-this sensitivity to external reproofs would later be an issue for him in the First World War. ${ }^{11} \mathrm{~A}$ strict disciplinarian tempered with a shrewd understanding of those he commanded, Steele did not descend into being a martinet. There were lines not to be crossed and, as one of his constables put it, he "was feared and respected by men who as a usual thing feared neither God or man."12 
The personification of the bluff and independent straight shooter, Steele was also a careful planner and administrator and determined to learn as much as he could about potential assignments. Contrary to the popular narrative, he was a political operator but was not particularly effective (to be discussed below).$^{13}$ Like almost all who reach the highest levels in any hierarchical organization, he leveraged his contacts, nurtured ties to his patrons, and was unafraid to pull any and all strings. Steele was careful to cultivate his relationship with Sam Hughes, the minister of militia, who had a notorious aversion to officers of the Permanent Force (PF) -Canada's regular army - when Steele was a member of the PF. He also relied on the powerful Western Canadian minister Robert Rogers to further his ends during the First World War, as attested to by the many diary entries, cables, and letters referencing Rogers. ${ }^{14}$

Steele was pragmatic on policing, as he recognized the difference between illegalities that had to be stopped and those that could not. He rigorously applied the former while controlling the latter through fines and licences. ${ }^{15}$ Steele and the Mounted Police maintained order with the tacit acceptance of the policed, as the NWMP did not have the resources to impose unacceptable rules and mores. He certainly imposed illegal orders, but they aligned with what the majority of the population thought reasonable.

On the negative side, Steele was prone to drinking spells when away from his wife. ${ }^{16}$ This may have impacted his career trajectory since the head of the South African Constabulary considered him a suitable replacement except for his binges. ${ }^{17}$ Reflecting the prevalent racial views of his class and time, he respected some Indigenous people and leaders, but he was unavailingly negative about people of Black African descent in South Africa and Canada. ${ }^{18}$

\section{Early Career}

Characteristically, Steele's determination to fashion his reputation meant he provided several dates for his birth ranging from 1848 to 1852 depending on the situation. ${ }^{19}$ The best evidence indicates Steele was born in Mediate Township, Ontario, on 5 January 1848, to a retired British Navy captain. Raised by his father and later his half-brother-thirty years his senior-to be a Victorian gentleman from the gentry class in the rustic backwaters of Upper Canada, Steele rapidly became a consummate horseman and shot. In 1866, he served in the Canadian Militia in the struggle against the Fenians. Military life appealed to him, and he left his career as a store clerk in rural Ontario to join the Red River Expedition of 
$1870 .{ }^{20}$ The gruelling physical effort, ever present danger, and strenuous struggles with the climate and terrain whetted his appetite for a military career. ${ }^{21}$ While in the garrison at Fort Garry, Steele demonstrated his foresight by querying everyone with experience about the Prairies, in case he was to serve there. ${ }^{22}$ After his discharge, he enlisted in the Permanent Force in Kingston. Wanting a more adventurous life, he signed up with the North-West Mounted Police (NWMP) when it formed in 1873 and was among the first group rushed to Fort Garry in the autumn of that year. The government established the NWMP ostensibly in response to the massacre of Indigenous people by American traders. Its actual purpose was multifold, including protection against the depredations of whiskey traders, assertion of Canadian sovereignty and control over the Canadian West, and, as Rod Macleod states, to act as "Agents of the National Policy" Steele would be involved with all these aspects. ${ }^{23}$

Steele operated throughout his NWMP career in the Canadian borderlands that were a transition zone between the Canadian heartland, the United States, and the realm of the Indigenous peoples. ${ }^{24}$ The senior NWMP command recognized his leadership strengths, and he rose quickly through the ranks. They treated Steele as a troubleshooter and deployed him to the most challenging assignments where he led or participated in almost all the major developments in the prairie frontier's transformation. These included the negotiations with Chief Sitting Bull (Tȟath̆ánka Iyothake) in 1877, the signing of treaties with the Plains Indigenous peoples, and the driving of the last spike at Craigellachie in 1885 . He was instrumental in policing the construction of the transcontinental Canadian Pacific Railway (CPR) by acting both as a police officer and magistrate. His powerful personality and innate good sense dampened down many volatile situations and ensured the line moved forward. Unlike most of the other senior Mounted Police officers, he emerged from the North-West Rebellion in 1885 with a burnished reputation in aggressively leading a small force of scouts. ${ }^{25}$ In 1887 the authorities sent Steele to the interior of British Columbia to prevent violence between the local Whites and the Ktunaxa (Kootenay) people. By the later summer of 1888, Steele, once again with his customary firmness and fairness, had defused the situation and returned to Alberta. ${ }^{26}$ He now commanded the largest division in the NWMP at Fort Macleod in Southern Alberta. It was then he married Marie Harwood, the daughter of a wealthy and well-connected Quebec member of parliament. Steele would try to leverage this family connection to advance his career, but to seemingly little result. The NWMP, like the military and civil service of the period, was subject to considerable 
patronage and political influence such that the authorities considered more than just performance in promotions and assignments. ${ }^{27}$ Not receiving the assistant commissioner's position in 1892 angered Steele. ${ }^{28}$ He had some justification for his disappointment as his record was superb, but this suggests that while he played the political game, he was not that skilled and possibly had clashed too often with party interests. ${ }^{29}$

\section{Yukon Career}

In January 1898 Steele received orders to reinforce police control in the Yukon during the stampede of thousands of gold-mad southerners to the North-of which many were foreigners of all "ilks" and "dispositions." The government was concerned that an anarchic situation would presage a loss of actual control over the territory and that had to be prevented. The government in Ottawa treated the Yukon as a colony of central Canada and was not democratic owing to the government's distrust of a populace with a minority of Canadians and of seemingly dubious character. ${ }^{30}$ Steele received substantial reinforcements to ensure he had the resources to impose order. Specifically, the NWMP were to establish border posts at all the major entry posts into the Yukon at the Chilkoot and White passes as well as at the Yukon River, to collect customs duties, and to police the gold fields and towns. Initially, Steele moved to Skagway, Alaska, the gateway through the passes to Dawson City, to mobilize logistics and make preparations. The mayhem and unfettered villainy of crime boss "Soapy" Smith and his gang, with their dishonest gambling, alcohol, graft, violence, and multiple methods of fleecing the unwary, was a powerful illustration of the risk of losing control-Steele called it "little better than hell upon earth." ${ }^{31}$ He then crossed over the Chilkoot Pass to inspect the border post in what must have been one of the most arduous stations ever staffed by the Mounted Police. ${ }^{32}$ Steele over-wintered at Lake Bennett, at the headwaters of the Yukon River, where thousands of the Klondikers anxiously awaited the ice breakup to race downriver to the gold fields. There, he worked long hours arbitrating disagreements and creating order out of what could have degenerated into bedlam. It was during the resulting rush downriver that Steele made a characteristic decision to mandate the use of guides through a particularly dangerous set of rapids. ${ }^{33}$ He did not have the authority to enforce this rule, but characteristically he was obeyed. In Dawson City, he dominated the situation. Steele seemed to never sleep and was constantly in action over the course of his nineteenhour day acting as a magistrate, Indian Agent, and health officer-creating and enforcing regulations, sitting on the territorial council, fulfilling 
the myriad civil service functions assigned to the police, checking on prisoners, confronting evil-doers, writing reports, and leading his men. ${ }^{34}$ Despite the ample opportunity for graft and corruption, there was no evidence that Steele or any of his mounted police crossed the line, which was a testament to Steele's leadership and firm control..$^{35}$

Steele's command was semi-independent as he reported not to the NWMP commissioner but to the territorial commissioner and Minister of the Interior Clifford Sifton. ${ }^{36}$ With communications in the winter taking weeks or months to pass between Dawson City and Ottawa, Steele had to make his own decisions and implement his own policies. This suited him ideally, and he took full advantage to achieve the objectives of peace and order. The vast majority of miners and others had no interest in the wickedness of the United States side of the border, so acquiesced with Steele's, and Canadian, laws and regulations. At times, Steele imposed arbitrary rules or adopted policies, like expelling criminals from the territory, that were illegal, but the majority of the populace understood and accepted them. Further, Steele appreciated the difference between what he could prohibit and what he could only regulate. The Mounted Police did not tolerate serious crimes like murder or theft, and they tirelessly tracked down these perpetrators. Steele and his policemen created an environment surprisingly free from major crimes given the rootless nature of the population. Trying to stop prostitution, gambling, or alcohol was a fruitless task in the gold rush, but prudent regulations could mitigate the most deleterious effects on peace and good order. As William Morrison phrased it, "the substitution of police common sense for orthodox legal knowledge and procedure was to become an important aspect of law enforcement in the Yukon." ${ }^{\prime 37}$ There were still ample opportunities for vice and sin, but Sam Steele and the NWMP moderated and regulated them.

Steele remained in charge of the police in the Yukon and British Columbia until 20 September 1899 when he was superseded-because he struggled against the corruption of the local officials - to the outrage of the vast majority of the populace. ${ }^{38}$ All three local newspapers that normally were at bitter loggerheads were in accord in their denunciations of the move. Despite rallies and multiple telegraph messages appealing the decision, the government remained unmoved. ${ }^{39}$

Steele was successful in this assignment because of scale, situation, problem, reputation, presence, and policy. The scale of the problem confronting him was reasonable. At the height of the deployment, Steele was responsible for 250 members of the Mounted Police, and he dealt directly with many issues and was only one level removed from the rest. ${ }^{40}$ 
The situation called for initiative, independent decision making, and direct action, all of which were his particular strengths. The problems he faced in the Yukon were similar to those he had dealt with successfully for twentyfive years, so he had a repertoire of proven techniques to accomplish his goals. His epic legend was a powerful aid and even if the majority of the inhabitants were not Canadians, the newcomers would quickly learn of his exploits. Allied with his reputation was his outsized presence and charisma that were a potent inducement to obey the law. Finally, his pragmatic policies, even if at times illegal, never violated the core values of the community and were accepted, albeit grudgingly at times.

\section{Military Career}

Steele was at a crossroads with the ending of his Yukon mission, as he had no other major assignment and the size and continued existence of the NWMP was in question. ${ }^{41}$ Fortuitously for him, conflict broke out between the Boers in South Africa and the British in what became the Second AngloBoer War, and he immediately volunteered for service in the Canadian 2nd Contingent. The "imagined community of British people" culturally conditioned Steele, like many of those who volunteered, to regard the Empire's call to duty as their own. ${ }^{42} \mathrm{He}$ was to be the second-in-command of a mounted rifle regiment to be drawn from the ranks of the NWMP, but he loyally stepped aside when the NWMP Commissioner Laurence Herchmer decided to lead the regiment. ${ }^{43}$ Instead, Donald Smith, Lord Strathcona, the wealthy financier, railway magnate, and now Canada's high commissioner in London, offered the British a regiment of Western Canadian scouts paid for by him. He selected Steele to command the unit, named Lord Strathcona's Horse (LSH), and Steele, with his customary energy and care, quickly recruited the regiment. ${ }^{44}$ Steele's carefully nurtured Canadian image for the unit helped develop a unique identity for the unit and himself. ${ }^{45}$ The regiment arrived as the war shifted from fixed engagements to a guerrilla war characterized by sudden blows by mobile Boer commandos pursued by ponderous British columns. Steele's personal leadership style, of being where the action was the hottest, was instrumental in developing high morale and combat effectiveness in a campaign marked by the frustrations of fleeting engagements, few tangible successes, and ever-present danger. ${ }^{46}$ Steele lost respect for the hesitant and ineffective British leadership, as well as the orders to burn farms and collect women and children to take to camps. ${ }^{47}$

Steele's period in command, however, was not without its controversy. While Steele was away, the regiment, believing its war was over, celebrated 
so much that the British called out several companies to bring back order. It appears the British commanders chalked the incident up to the expected behaviour of wild colonials. ${ }^{48}$ An officer in the LSH, the wealthy Agar Adams, while initially impressed with Steele, accused him of being a bully and "treating the men like animals." ${ }^{49} \mathrm{He}$ also claimed Steele and his officers got "beastly drunk" and left the men to their own devices. Macleod, in his Dictionary of Canadian Biography entry on Steele, argues persuasively that Adamson's complaints were at least exaggerated, for one enduring characteristic of Steele was his care for his men. The other incident was more serious and involved a war crime where LSH troops assisted in hanging six Boers after men from another regiment suffered casualties when fired upon under a flag of truce. Carmen Miller believes the case was covered up, but there was no suggestion that Steele was directly involved in the war crime..$^{50}$

The LSH returned to Canada in 1901 after a successful tour in England where the British government, newspapers, and people feted them. Before leaving South Africa, Lord Baden-Powell, of later Boy Scouts fame, offered Steele a divisional command of a thousand constables in the new South African Constabulary (SAC) - a force similar in form and purpose to the original NWMP. As the government was not yet ready to convert the LSH into a permanent Canadian military unit, Steele accepted the offer as he did not intend to return to the NWMP. ${ }^{51}$ His experience on the prairies, and Baden-Powell's confidence in Steele, meant that Steele helped shape the SAC. Baden-Powell thought him a potential successor to command, which was a considerable mark of esteem for a colonial officer. ${ }^{52}$ Steele served for five somewhat frustrating years with the SAC, since the authorities spread the Canadians he recruited for the force across all the divisions rather than concentrated under his command. ${ }^{53}$ In 1906, he left the SAC to serve a further eight months in England as a staff officer to Baden-Powell, who was then the Inspector of Cavalry. ${ }^{54}$

In 1907 Steele returned to Canada to join the PF with the rank of lieutenant-colonel. The Canadian military comprised the tiny PF of regulars and a nominally 70,000-man non-permanent active militia in 1914-hereafter referred to as the Militia. The PF was responsible for training the Militia, but there was considerable friction between the two forces because of competition over limited funding. ${ }^{55}$ High personnel turnover and restricted opportunities for its own training hampered the PF. ${ }^{56}$ However, under the reforming Liberal Minister of Militia and Defence Frederick Borden, a cousin of the later Conservative prime minister Robert Borden, the Canadian military underwent a considerable 
transformation in organization, budget, and the ability to field complete units. ${ }^{57}$ The annual budget for the military increased from $\$ 3$ million in 1904 to $\$ 13$ million in 1914, and the size of the Permanent Force grew from 900 to 3,100 in $1914 .{ }^{58}$ Steele first assumed command of Military District \#13, which encompassed all the Militia units located in Alberta and the District of Mackenzie. In May 1909 he transferred to the more important post of commander of Military District \#10 headquartered in Winnipeg, which he held at the start of the First World War. The district included the provinces of Manitoba and Saskatchewan and the western parts of Ontario, and his old command, Lord Strathcona's Horse, was now a part of the PF. ${ }^{59}$

\section{$2^{\text {nd }}$ Division}

Steele continued in his command of Military District \#10 through the early part of the war, with his district raising two battalions each for the 1st and 2nd Divisions. ${ }^{60}$ In February 1915 Sam Hughes appointed Steele to command the 2nd Division, which the British had accepted after a Canadian offer for a second contingent on 31 October $1914 .{ }^{61}$ Instead of mobilizing centrally, as did the 1st Division, the authorities formed and stationed the 2nd Division's units locally where they trained over the winter. ${ }^{62}$ Choosing Steele to command the 2 nd Division was a convoluted process. The British selection of the former British cabinet minister J.E.B. Seely, without consultation, to command the Canadian Cavalry Brigade, goaded the Canadian Prime Minister Robert Borden to ensure that a Canadian commanded the 2nd Division. ${ }^{63}$ Borden dissuaded Hughes from taking the command, and instead Hughes recommended Steele for the post for his proven organizational skills. ${ }^{64}$ Steele's selection also had the merit of his considerable prestige, and satisfying the demands of powerful cabinet minister Robert Rogers for equal representation for Western Canada in the command ranks-eastern officers commanded two of the three brigades in the 1st Division. ${ }^{65}$

When Hughes proposed Steele to Lord Kitchener, the British secretary of state for war, Kitchener rejected Steele on account of his age (sixty-six) and lack of staff training. He knew him from his service in the Boer War when Kitchener commanded the British army in South Africa. Despite the suggestion that his age was an unwarranted objection, Steele ostensibly at sixty-six years old was eleven years older than the average British division commander and twenty-two years older than the average Canadian one in $1915 .{ }^{66}$ Further, there were questions about Steele's health, with the official Canadian Medical History claiming he was suffering from an incurable 
malady. ${ }^{67}$ Hughes, later in 1916, thought Steele was on his last legs. ${ }^{68}$ Kitchener was correct to reject Steele for duty in France.

Hughes and the British authorities eventually agreed that Steele could bring the division to England but not take it to France, and would receive a position commensurate with his prominence. As Steele was a commissioned officer in the British Army as a result of his command of LSH, Kitchener assigned him the Southeastern District in England. This was a training command that included Shorncliffe, the major Canadian instruction centre. ${ }^{69}$ Hughes also made him the GOC-Canadians despite there already being a GOC-Canadians appointed in February 1915Brigadier-General J.C. MacDougall, another PF officer-an oversight that would generate much heat between the two men. ${ }^{70}$ Losing the division was understandably a deep disappointment to Steele as he believed himself fully capable of commanding in action..$^{71}$ According to his former aide-de-camp, Steele was popular with many officers and men in the division, but the new commander-Major-General Richard Turner with a Victoria Cross and combat experience on the Western Front-quickly won them over. ${ }^{72}$ Not everyone thought Steele competent; Harold McGill, the medical officer of the 31st Battalion, wrote that when Turner took over the division, "there was a feeling of profound relief, among many of us at least." ${ }^{\prime 3}$ Another commented that the division's British chief staff officer spoke for himself and not Steele, which was against staff practice, but under Turner he was careful to follow this policy. British staff officers were always supposed to be a representative of the commander and never speak for themselves on official matters. This suggests a lack of respect for Steele. ${ }^{74}$ In training, Steele had his units conduct training exercises as meeting engagements, an approach characterized by a leading military historian as more appropriate for the Franco-Prussian War and something rarely if ever encountered on the Western Front. ${ }^{75}$ While in command, Steele, however, took a positive step in weeding out unqualified officers selected by Sam Hughes, including two brigadier-generals and a battalion commander. ${ }^{76}$

\section{First World War Context}

The scale, scope, and nature of the First World War were unprecedented challenges for Canada, as it vastly increased its army from one PF regiment to fifty active service battalions by the end of the war. ${ }^{77}$ The factors of distance, lack of experience in raising and maintaining overseas forces, having to report to both British and Canadian authorities, and the rapidly evolving nature of the war, magnified the problem. The scale of the losses 
in the First World War was immense and necessitated the Canadian authorities to improvise a massive recruiting and training infrastructure in Canada and England. ${ }^{78}$ Inevitably, mistakes were made, but the tragedy was Canada's retention of the faulty system and incompetent commanders until late 1916. The war placed unprecedented demands on the Canadian military, so it was not surprising that there were initial failures. These errors were understandable, but after two years, however, the Canadian system in England was not improving and inexperience was no longer an excuse. The administration was not addressing the problems of inefficiency, ineffectiveness, and promotion inequities. This was in stark contrast to the increasing professionalism and effectiveness of the Canadian forces at the front. If the field forces could master a steep learning curve, so should have the Canadian administration in England.

Canadian training units in England were under the operational, administrative, disciplinary, logistical, and, until late 1916, instructional control by various area commands, such as Eastern Command to which Steele reported. The result was that Canadian forces followed British regulations in most matters. Steele's position was a difficult one as he had two different sets of superiors who had different agendas and demands. As an officer of the British Army in command of a district, he reported to the general in charge of the Eastern Command of British Home Forces and had to follow British rules and regulations. He was also a Canadian officer with a Canadian Training Division (CTD) in his district and was nominally the general commanding all Canadian forces in England. ${ }^{79}$ He therefore also reported to Sam Hughes, who had control over his professional career and who had a well-known dislike of PF officers. ${ }^{80}$ As a result, Steele would not confront Hughes over the myriad problems in the system and could not circumvent the rules and regulations like in the Yukon.

The structure of Canadian forces in England was a confusing mess of feuding officers, civilians, and ministerial representatives. At one point in 1916, six separate authorities in England claimed to speak for Canada. They included the acting high commissioner Sir George Perley; Max Aitken, Hughes's personal representative; Lord Brooke and later David Watson, the commanders of the Bramshott CTD; Major-General J.C. MacDougall, the original GOC-Canadians in charge of the Shorncliffe CTD; MajorGeneral John Wallace Carson, Hughes's "Special Representative"; and Steele, the GOC Southeastern District, and another GOC-Canadians. This naturally confused the War Office, which at one point plaintively asked who was in charge. ${ }^{81}$ The answer, ultimately, was-Sam Hughes, who used 
this ambiguous command structure to ensure he made all the important decisions. This contributed to the poor coordination and jostling for Hughes's attention between the different parties and their subordinates. For instance, Steele wrote to John Carson on behalf of senior officers at Shorncliffe who were eager to meet Hughes on his visit to England in July 1916 as they feared that "he is not in possession of true facts relative to them and their work." 82

This confusing structure developed rapidly once the 1st Division left for France in February 1915. As new units arrived, the authorities added more training areas that would report to different British commands. By late 1916, the Canadian organization consisted of fifty-seven reserve battalions scattered across six major centres, split into two training divisions at Shorncliffe and Bramshott, each reporting to a separate British command. Carson, a stout mining-stock promoter, adroitly manoeuvred a poorly defined set of responsibilities into a position of being the de facto authority for the feuding Canadian major-generals in the training commands and the British. Carson impressed Borden in his initial foray as a special representative in 1914, and Borden extended Carson's mandate to be the communications nexus between the British, the Canadian authorities in France and England, and Hughes. Carson entirely depended on Hughes's favour and so was certain to satisfy him even when he disagreed with the minister's demands. ${ }^{83}$ Carson told another senior officer that he "was obliged to do things, by order of the Minster, of which he did not approve." 84

Other officers ignoring his nominal position as GOC-Canadians was intensely frustrating to Steele. ${ }^{85}$ For instance, the querulous Steele blasted Carson for bypassing him regarding requests for recommendations on rewards to his subordinates, "I contend that I must not be passed over and ignored in the way I have been." ${ }^{\prime 6}$ In early 1916, Steele complained to Hughes that Carson does not seem to understand his status and that Carson's meddling "is a scandal." ${ }^{87}$

\section{Problems with Canadian Administration}

Every facet of the Canadian military administration in 1915 and 1916 was defective, from the quartermaster branch to the chaplain service to, most importantly, the training of the combat arms and officers. This failure had drastic, deleterious consequences, as it seriously compromised the Canadian Corps' ability to sustain its edge. Officers at the front complained, the British complained, and even Borden complained about the disorganization and misrule. From early in the conflict, there was 
constant criticism of the administration. An example was a complaint sent by a $5^{\text {th }}$ Brigade officer to Borden that: "Canadian soldiering arrangements in England are in a deplorable state." ${ }^{\prime 88}$ His was not the only letter, and the files show much discontent and anger. A report on the training system included this damning critique: "the conception and tone of the Canadian Training Division is on a wrong basis from its foundation." ${ }^{89}$ The commander of the Canadian Corps complained to Hughes in February 1916 that there is "a strong and growing conviction, among all my Divisional, Brigade and Battalion Commanders, that the best possible is not being done, as regards these drafts." ${ }^{\prime 90}$ The commander of the British Expeditionary Force, General Sir Douglas Haig, after discussions with the new Canadian Corps commander, Sir Julian Byng, in June 1916, wrote, "his recent drafts have been badly trained, and he told me that the Canadian organisation at Shorncliffe is a disgrace." ${ }^{\prime 11}$ In December 1915 Major-General Arthur Currie complained that the artillery instruction was "d-d rotten and the men responsible for the training of these men should be told so in no unmistakable terms." ${ }^{\prime 2}$

The training of replacements for the combat arms was the responsibility of the CTD at Shorncliffe, which reported to Steele. The complaints about the officers and men sent to the front regarded the numbers provided and the effectiveness of their instruction. The training system had great difficulty in providing sufficient replacements when the corps suffered heavy losses. The first major engagement of multiple divisions of the Canadian Corps at the Battle of Mount Sorrel in June 1916 resulted in 8,000 casualties. $^{93}$ The training system was unprepared for this scale of losses, and the authorities had to strip the 4th Division that was forming in England and scheduled to cross to France in July. For instance, the 46th Battalion lost $80 \%$ of its personnel in June. ${ }^{94}$ As a result, just as the division was in its final preparations, it had to start training recruits all over. The 24,000 casualties on the Somme threw an insupportable burden on the training establishment, and it collapsed. By 8 November, the corps was short 296 officers, with only sixty-five replacements ready. The infantry needed 9,368 drafts, but only 2,923 partially trained replacements were available, leaving a shortfall of 6,445 men. ${ }^{95}$ This at a time when there were over 78,000 men in England in training, administration, or acting as instructors. ${ }^{96}$

Not only were there too few men, those arriving were unprepared for battle. The Canadian syllabus was a scant ten weeks, which was insufficient time to instruct the recruits properly-the British War Office course was fourteen weeks. ${ }^{97}$ In most instances, recruits did not complete 
their full instruction period; 59.2\% of all the replacements provided in 1916 were only partially trained, and during the Somme in October 1916, the proportion rose to a shockingly high seven out of ten men not fully trained as the Shorncliffe CTD rushed men to the front to replace losses. ${ }^{98}$ Even the limited preparation was often on outmoded principles and obsolete manuals. ${ }^{99}$ In one remarkable example of how out of touch the training personnel were, a staff officer at Shorncliffe stated in the fall of 1916 that the "Lewis machine gun is apparently being used in the Canadian Corps" - this a year after its introduction at the front. ${ }^{100}$

The quantity and quality of replacement officers was another problem. ${ }^{101}$ In early 1916, Shorncliffe had only $7 \%$ of its officers immediately available for drafts and another $8 \%$ after completing courses. ${ }^{102}$ The corps complained that officers arriving from England did not have sufficient practical training to be effective to the extent that the corps established a school for them. ${ }^{103}$ Steele had to issue an order that all officers were to know their men-it was extraordinary that they were unaware of this most basic of responsibilities. ${ }^{104}$

These failures had disastrous repercussions on the battlefield during the Somme. For example, the shortage of replacements meant the 5th Brigade went into battle on 1 October 1916 with slightly more than half of its normal trench strength, with the result the Germans defeated its attack. ${ }^{105}$ The 1st and 3rd Divisions attacked on 8 October with battalions with an average strength of 400 to 500 men, roughly two-thirds of what they should have had. ${ }^{106}$ Another factor in the defeat was that the newly arrived replacements from England had not fired the rifle employed, nor had experience with grenades used at the front. ${ }^{107}$

\section{Steele's Culpability}

To what extent was Steele responsible or culpable for this lamentable situation? He was by no means the main culprit or factor in the chaosSam Hughes was the primary offender-but he bears responsibility. Steele did attempt to address some of the issues as his diary attests. He regularly chided MacDougall and staff over their poor performance. There are regular references to his orders to the CTD for closer supervision, for surprise inspections, and for other improvements. ${ }^{108}$ He recognized that not all was well with it, as "I feel very much dissatisfied with the state of affairs in the Canadian division." 109 He also claimed he was not permitted to interfere with the Shorncliffe CTD, which was a curious assertion as it was under his command. ${ }^{110}$ However, Steele's efforts were unavailing and the abysmal conditions were not effectively addressed. 
Part of the issue was Steele's refusal to accept reproof from the front on the quantity and quality of replacements. ${ }^{111}$ This attitude was intensely frustrating and led to comments from senior officers like Arthur Currie, then commanding the 1st Division: "I almost feel as if it is no further use making complaints, because the position is almost hopeless." ${ }^{112}$ The situation was so bad that the commander-in-chief of the home forces in England stated his satisfaction that the new Canadian administration brought in December 1916 was willing to accept criticisms unlike the previous regime. ${ }^{113}$ As a result of this sensitivity to criticism, Steele did not take sufficient steps to reform what he controlled. Conditioning Steele's response to the complaints was his contempt for Militia officers. There are references in his diary disparaging them, such as "some of these militia seem to feel that they know it all" and "petty shopkeepers in charge."114 During the Somme campaign, $81 \%$ of the senior combat commanders in the Canadian Corps were Militia officers with only 14\% being from the PF. ${ }^{115}$ This cohort of officers built the Canadian Corps with $83 \%$ still serving at the great victory at Vimy Ridge. ${ }^{116}$ Steele underestimated the Militia contribution and how the unique conditions of the Western Front differed from his own experiences in South Africa.

Steele also, according to the available files, letters, and diary entries, did not confront Hughes about the problems in the system other than send some suggestions for improvements, although he thought Hughes a fraud as a soldier. ${ }^{117}$ Desmond Morton wrote that Hughes had terrorized the PF officers like MacDougall and Steele so they would not question the minister. ${ }^{118}$ He well knew Hughes's reaction to an adverse report and counselled the British authorities that it would result in "the officers who made it being dismissed from the Canadian service for their temerity."119 Further, when meeting with Hughes, Steele would bolster Hughes's prejudices and opinions. For instance, in a 22 March 1916 diary entry, Steele wrote that when asked by Hughes about the Ross Rifle, much despised by the troops in the field, "I said the men who had the Ross would not exchange it for the Lee Enfield." 120

By October 1916 Borden could no longer ignore the chaotic situation in England, and he made major changes. In November, he secured Hughes's resignation and split the Ministry of Militia into two separate ministries, with one for Canada and one overseas. The acting high commissioner, Sir George Perley, headed the new overseas ministry, and he selected the commander of the 2nd Division, Major-General Richard Turner, to command the Canadians in England. Turner and his staff implemented wide-sweeping reforms that increased the effectiveness of the training 
organization, improved its efficiency, and refashioned the promotion system. What was remarkable was how swiftly these changes took effect. ${ }^{121}$ This suggests the problems with the previous regime were not inherent, but ones stemming from weak commanders and administrative structure.

Recognizing that the changing of the guard represented both an opportunity and a threat, in November 1916 Steele sent Perley a long letter recommending how to organize the new ministry and who should be in charge. He was confident about his abilities and suggested Perley should appoint him the ministry's inspector general or, even better, the commanding officer as he was especially suited to that role. ${ }^{122}$ Steele was thoroughly convinced he was both greatly respected by the officers and men of the CEF and that they wanted him in command; Steele wrote in his diary in regards to a rumour of a new corps commander, with the previous one taking command in Canada, that "This is an outrage ... one or the other [commands] is my right." ${ }^{123}$ It is far more likely that their esteem was for his accomplishments dating back to his service with the NWMP and the LSH than for his performance in the First World War. He found subordination to Turner, who was a more junior Militia officer and had "taken his division," "very annoying." 124 Wanted neither by Perley nor Turner, they removed Steele from his Canadian command, but he retained the British Southeastern District until 1918. ${ }^{125}$ Likely his dismissal was a result of being seen as too closely aligned with the old regime, his age, the poor results of his command, and his constant back-channel stringpulling. He got into particularly hot water in June 1917 when he wired Robert Rogers advocating for the promotion of his protégé BrigadierGeneral HDB Ketchen to lead a division-Ketchen had served under Steele in the NWMP, LSH, and in MD\#10. Perley suggested to Borden that it was time for Steele to return to Canada. ${ }^{126}$ Steele, however, remained in England, but retired in July 1918 and died from influenza in January 1919.

Why was Steele so much less successful in England than during his period in the Yukon? This time, the factors of scale, problem, location, and personal considerations all negatively affected his performance. In command of the Southeastern District, Steele operated at an entirely different scale than in the Yukon, which included several times more men than there were people in the Yukon in 1899. He was responsible for approximately 250 mounted police in the Yukon and British Columbia force, while the Shorncliffe CTD had a strength of over 40,000 men. Further, in England he was four stages removed from the training and only dealt directly with it on inspections. ${ }^{127}$ His information and his decisions had to 
pass through several levels of delegation, which required a different skill set than dealing directly with problems.

In England, he faced a new set of challenges for which he had little to no relevant experience. His active military service was always as a mounted rifle officer and so he had little exposure to the infantry or technical arms, such as the artillery or engineers, outside of his period in charge of the military districts. He had limited knowledge of the conditions of the front, in part because he could not visit the Canadian Corps and did not appreciate the changing nature of the war as a result. The situation on the Western Front was unique and in constant change such that the Canadian Corps later in the war would not accept an officer who had been away from the front for more than six months. ${ }^{128}$ Even the senior British general Sir William Robertson lamented "each war has its own peculiarities, but one would think that no war was ever so peculiar as the present one, and Field Service Regulations will require a tremendous amount of revising..."129 Steele's refusal to accept criticism and his dismissal of Militia officers meant he did not appreciate the extent of the failure in training. Rather than viewing his organization as a servant of the fighting troops, he regarded it as a co-equal and above reproach.

No longer on the frontier, he was now at the heart of the Empire and integrated into a chain of command with virtually instant communications with many masters and agendas. He now had to satisfy different and sometimes conflicting demands, something he had little experience with. Rigid British rules and regulations as well as the changing Canadian situation constrained his options, and so he did not have the freedom to improvise. Further, he was limited in his authority without referring to his superiors for approval, which seems to have sapped his initiative. Despite his elevated rank in England, he was just a cog in a larger machine rather than the key figure as he was in the Yukon.

In 1898-1899, he was in the prime of life and had the benefit of twentyfive years of relevant experience in police matters. By the time of the First World War, he was seventeen years older, more corpulent, and while he still worked hard, the fire was absent. Infighting and trying to get the other major-generals, who were behaving badly, to obey him absorbed too much of his energy. That they did not comply despite his nominal title of GOC-Canadians indicates the extent to which his power had eroded. Having to continually claim to be in charge, but being ignored, means you are not in charge. Further, matching a pattern from earlier in his life, his attempts to bring political influence to bear and to work back channels were to no avail. Even Steele lost confidence in the cabinet minister Robert 
Rogers's ability to accomplish much for him, and his choice of political patrons in Rogers and Hughes was unwise. ${ }^{130}$ Further, he badly misjudged his standing with the authorities outside of the Hughes and Rogers cliques, and Perley and Turner stripped him of his Canadian command. While still admired for his accomplishments as a mounted policeman, his more recent military achievements were too modest to justify continued responsibilities.

\section{Conclusion}

This article demonstrates how one of the great figures in the early days of the Yukon floundered under the strains of total war. In the Yukon, Steele's natural decisiveness and independence received free rein, where he did not have to defer and get approval from multiple authorities for decisions, and where the scale of his responsibility was such that he could directly interact with all involved. In those conditions, Steele thrived. He was a leader made by the frontier and performed best in that environment, and his real accomplishments there should not be sullied by his less successful career during the First World War. In England, now in the centre and far from the frontier, the attributes, character, and experience that served him so well did not translate. Steele was not the primary culprit or cause of the chaos in the administration in England, but neither was he blameless or innocent of contributing to it. In effect, the Lion of the Frontier became the Lion in Winter.

\section{Author}

William F. Stewart is an independent historian and author of The Embattled General: Sir Richard Turner and the First World War (McGill-Queen's University Press, 2015).

\section{Notes}

1. Robert Stewart, Sam Steele: Lion of the Frontier (Toronto: Doubleday Canada, 1979).

2. Steele to Carson, 14 Nov 1916, 8-1-35, RG9 III-A-1 v29, Library and Archives Canada (LAC).

3. Stewart, Lion of the Frontier.

4. Examples include William Beahen and Stan Horrall, Red Coats on the Prairies: The North-West Mounted Police, 1886-1900 (Regina: Centax Books, PrintWest Pub. Services, 1998); Kenneth Coates and William R. Morrison, Land of the Midnight Sun: A History of the Yukon (Edmonton: Hurtig, 1988); William R. Morrison, Showing the Flag: The Mounted Police and Canadian Sovereignty in the North, 1894-1925 (Vancouver: University of British Columbia Press, 1985). 
5. R.C. Macleod, "Dictionary of Canadian Biography Online-Steele, Sir Samuel Benfield," 19 March 2013, http://www.biographi.ca/en/bio/steele samuel benfield 14E.html.

6. John West Chalmers, Horseman in Scarlet: Sam Steele of the Mounties, Frontier Books No 1 (Toronto: W. J. Gage, 1961); Stan Garrod, Sam Steele, The Canadians (Don Mills, Ont.: Fitzhenry \& Whiteside, 1979); Norman Leach, Sam Steele: An Officer and a Gentleman (Toronto: Dundurn Press, 2015); Holly Quan, Sam Steele: The Wild West Adventures of Canada's Most Famous Mountie, Amazing Stories (Canmore, Alta.: Altitude, 2003).

7. This was the policy of the new regime that replaced Steele in 1917. Stewart, Lion of the Frontier, 280; William F. Stewart, The Embattled General: Sir Richard Turner and the First World War (Montreal \& Kingston: McGill-Queen's University Press, 2015), 178-9.

8. Samuel B. Steele, Forty Years in Canada: Reminiscences of the Great North-West with Some Account of His Service in South Africa, The Ryerson Archive Series (Toronto, New York: McGraw-Hill Ryerson, 1972).

9. For instance, Steele referenced gossip in his diary that the minister of militia laughed about an incident where he had fallen off his horse at a parade the previous year. Sam Steele Diary, 1 Feb 1916, 2008.1.1.2.68, Steele Fonds, Bruce Peel Special Collections, University of Alberta (BPSC).

10. For more on the "longue durée" effects of the Mounted Police on the Prairies, see Pascual Restrepo, "The Mounties and the Origins of Peace in the Canadian Prairies," accessed 7 Feb 2016, http://papers.ssrn.com/sol3/ Papers.cfm?abstract id=2670737.

11. Beahen and Horrall, Red Coats, 248.

12. Stewart, Lion of the Frontier, 30.

13. Ibid., 283.

14. For example, Perley to Borden, 28 June 1917, RG9 III-A-1 v107, Library and Archives, Canada (LAC); Desmond Morton, A Peculiar Kind of Politics (University of Toronto Press, 1982), 72; Steele Diary, 13 May, 1 Jun 1916, BPSC.

15. Morrison, Showing the Flag, 23.

16. Steele, 40 Years, "DNB-Steele."

17. Carman Miller, Canada's Little War (Toronto: J. Lorimer, 2003), 79.

18. He wants to discharge a "negro" as "it is not desirable to recruit from this race." Steele to Carson, 27 Jun 1916, 8-5-10e, RG9 III-A-1 v45, LAC; Steele, 40 Years, 375-376.

19. His attestation paper lists his birth year as 1852 as he wanted to appear younger than he was actually. Samuel Benfield Steele Service Jacket, RG150 Acc92-93/166 v9259-30, LAC; Mary Flynn, "Happy Birthday, Sam Steele!," accessed 28 Feb 2016, http://steele.library.ualberta.ca/news-item/451.

20. Steele, 40 Years, 12.

21. Stewart, Lion of the Frontier, 26.

22. Steele, 40 Years, $44-47$. 
23. Beahen and Horrall, Red Coats, 14.

24. David Newman, "Contemporary Research Agendas in Border Studies: An Overview," in The Ashgate Research Companion to Border Studies, ed. Doris Wastl-Walter (Burlington, VT: Ashgate, 2011), 37.

25. Beahen and Horrall, Red Coats, 6.

26. Ibid., 59-60.

27. Ibid., 263.

28. Stewart, Lion of the Frontier, 200.

29. Steele to Carson, 27 Jun 1916, LAC.

30. Morrison, Showing the Flag, 37; Coates and Morrison, Midnight Sun, 109.

31. Morrison, Showing the Flag, 35.

32. Stewart, Lion of the Frontier, 216.

33. Steele, 40 Years, 311.

34. Coates and Morrison, Midnight Sun, 97.

35. Charles Wilkins, The Wild Ride: A History of the North-West Mounted Police, 1873-1904 (Vancouver: Stanton Atkins \& Dosil, 2010), 221.

36. Morrison, Showing the Flag, 33.

37. Ibid., 23.

38. Stewart, Lion of the Frontier, 238.

39. Charlotte Gray, Gold Diggers: Striking It Rich in the Klondike (Berkeley: Counterpoint, 2010), 337, 348.

40. Ibid., 288.

41. Stewart, Lion of the Frontier, 242.

42. Paul Maroney, “The 'Peaceable Kingdom' Reconsidered: War and Culture in English Canada, 1884-1914” (PhD diss., Queen's University, 1996), 200, 284.

43. Stewart, Lion of the Frontier, 244.

44. The regiment is now part of Canada's regular army.

45. Miller, Canada's Little War, 75.

46. Kenneth Grad, "Effective Leadership in Counter-Insurgency: The NorthWest Mounted Police in South Africa, 1899-1902," Canadian Military Journal, accessed 7 Jan 2016, http://www.journal.forces.gc.ca/vo9/no2/08-grad-eng.asp.

47. Miller, Canada's Little War, 75; Grad, "Effective Leadership."

48. Miller, Canada's Little War, 76.

49. Sandra Gwyn, Tapestry of War: A Private View of Canadians in the Great War, 1st ed. (Toronto: HarperCollins, 1992), 81.

50. Steele to Carson, 27 Jun 1916, LAC.

51. Steele, 40 Years, 363.

52. Miller, Canada's Little War, 79.

53. Steele to Carson, 27 Jun 1916, LAC.

54. Stewart, Lion of the Frontier, 270.

55. James A. Wood, Militia Myths: Ideas of the Canadian Citizen Soldier, 1896-1921 (Vancouver: UBC Press, 2010), 58. 
56. Richard Gottfrid Larsson Holt, "Filling the Ranks: Recruiting, Training and Reinforcements in the Canadian Expeditionary Force 1914-1918" (PhD dissertation, University of Western Ontario, 2011), 17.

57. For more on Borden's accomplishments, see Carman Miller, A Knight in Politics: A Biography of Sir Frederick Borden (Montreal: McGill-Queen's University Press, 2010).

58. William Beahen, "A Citizens Army: The Growth and Development of the Canadian Militia, 1904-1914" (PhD diss., University of Ottawa, 1979), 130.

59. Department of Militia and Defence, The Quarterly Militia List of the Dominion of Canada (Corrected to June 30, 1914) (Ottawa: Department of Militia and Defence, 1914).

60. The 5th and 7th Battalions for the 1st Division and the 27th and 28th Battalions for the 2nd Division.

61. A. Fortescue Duguid, The Canadian Forces in the Great War 1914-1919, vol. 1 (Ottawa: Minister of National Defence, 1938), 404.

62. Holt, "Filling the Ranks," 125.

63. Carson to Hughes, 23 Feb 1915, 8-5-10, RG9 III-A-1 v45, LAC; Borden to Hughes, 19 Feb 1915, 31762, MG26 H v62, Borden Fonds, LAC.

64. Hughes to Borden, 25 Feb 1915, 31763, MG26 H v62, Borden Fonds, LAC.

65. J. L. Granatstein, Canada and the Two World Wars (Toronto: Key Porter Books, 2003), 65.

66. Steele was likely 67 , although his main popular biographer thought him 64 . Stewart, Lion of the Frontier, 275, 278; Simmon Robbins, "British Generalship on the Western Front, 1914-1918" (PhD diss., King's College London, 2001), 169, 527; Age of GOC in the Canadian Corps, GAQ 10-55, RG24 v1843, LAC.

67. Andrew Macphail and Canada Department of National Defence, Historical Section. Official History of the Canadian Forces in the Great War 1914-19. The Medical Services (Ottawa: F. A. Acland, 1925), 46.

68. Morton, A Peculiar Kind of Politics, 76.

69. Major-General Sir Samuel Steele File, S-9, MG27 II D9 v161, Kemp Fonds, LAC; Command of the 2nd Division, WG/3-WG/17, PRO 30/57/56, Kitchener Papers, The National Archives, London (TNA).

70. Biography of J.C. MacDougall During War, G.A.Q. 4-40, RG24 v1815 LAC.

71. Narrative in Regard to Major-General Sir S.B. Steele, 3 Jan 1918, S-9, MG27 II D9 v161, Kemp Fonds, LAC.

72. Observations of Montague Relating to Turner Taking over 2nd Division; Undated, 19710147-015/DOCS MANU 58A 1 9.14, Turner Fonds, Canadian War Museum (CWM).

73. Harold W. McGill and Marjorie Norris, Medicine and Duty: The World War I Memoir of Captain Harold W. McGill, Medical Officer, 31st Battalion, C.E.F. (Calgary: University of Calgary Press, 2007), 67.

74. In the British command system, staff officers were to speak for their commanders and not themselves. Macphail Diary, 17 Aug 1915, MG30 D150 v4, Macphail Fonds, LAC. 
75. 2nd Division GS War Diary, Appendix A, June and July 1915, RG9 III-D-3 v4841, LAC. Peter Simkins, Kitchener's Army: The Raising of Britain's New Armies, 1914-1916 (Manchester: Manchester University Press, 1988), 307.

76. Stewart, Embattled General, 76-77.

77. Forty-eight infantry battalions concurrently served in the Canadian Corps and two in the Canadian Expeditionary Force (Siberia). G. W. L. Nicholson, Canadian Expeditionary Force, 1914-1919 (Ottawa: R. Duhamel, Queen's Printer, 1964), 519; Benjamin Isitt, From Victoria to Vladivostok: Canada's Siberian Expedition, 1917-19 (Vancouver: UBC Press, 2010).

78. For more on the topic, see Holt, "Filling the Ranks."

79. Narrative in Regard to Major-General Sir S.B. Steele, 3 Jan 1918, LAC.

80. Morton, A Peculiar Kind of Politics, 42; Tim Cook, At the Sharp End: Canadians Fighting the Great War, 1914-1916 (Toronto: Viking Canada, 2007), 41.

81. Ronald Haycock, Sam Hughes: The Public Career of a Controversial Canadian, 1885-1916 (Wilfrid Laurier University Press, 1986), 267.

82. Steele to Carson, 21 Jul 1916, 8-5-10e, RG9 III-A-1 v45, LAC.

83. Biography, J.W. Carson, RG24 v6930, LAC; Connaught to Kitchener, 31 May 1915, WG/41, PRO 30/57/56, Kitchener Papers, The National Archives, London (TNA); Morton, A Peculiar Kind of Politics, 32-33, 71; Macphail Diary, 9 Feb 1916, MG30 D150 v4, Macphail Fonds, LAC.

84. Meighen to Duguid, 23 Nov 1936, HQ 683-1-30-5, RG24 v1503, LAC.

85. Carson to Hughes, 4 Dec 1915, LAC, 8-1-26, RG9 III-A-1v35, LAC; Steele Diary, 4, 6 April, 18 Jun 1916, BPSC.

86. Steele to Carson, 14 Nov 1916, LAC.

87. Steele Diary, 17 Jan 1916, 6 Apr 1916, BPSC.

88. Borden to Perley, 17 Mar 1916, MG27 II D12 v4-7, Perley Fonds, LAC.

89. Lessard Report, May 1916, GAQ 10-39, RG24 v1840, LAC; Summary of General Conditions Which Existed Prior to Assumption of Command by Major-General R.E.W. Turner, 23 Feb 1917, MG30 E46 v6, Turner Fonds, LAC.

90. Alderson to Hughes, 16 Feb 1916, 8-5-8D RG9 III-A-1 v44, LAC.

91. Haig Diary, 23 Jun 1916, Part 1 No. 96, Haig's Autograph Great War Diary, Haig Papers, National Library of Scotland (NLS).

92. Currie to Carson, Dec 1915, 8-7-1, RG9 III-A-1 v52, LAC.

93. Nicholson, CEF, 154.

94. James L. McWilliams, and James L. Steel, The Suicide Battalion (Edmonton: Hurtig, 1978), 25.

95. Maj. Macfarland A/DAG to Carson, 17 Oct 1916, 8-1-7b, 9/52, RG9 III-A-1 v52, LAC; Outstanding Reinforcements, 8 Nov 1916, 8-1-7b, 9/52, RG9 III-A-1 v52, LAC.

96. Strength Return, 8 Nov 1916, O-153-3 v1, RG9 III-B-1 v2892, LAC.

97. Steele to Carson, 4 May 1916, 8-5-10d RG9 III-A-1 v45, LAC; Visit to France of Dep. Min. ASMC, 3 Nov 1916, RG9 III-A-1 v107, LAC; Holt, "Filling the Ranks," 298, 551. 
98. Holt, "Filling the Ranks," 500.

99. Canadian Signalling School, 1 Dec 1918, 113/5, RG9 III-D-1 v4718, LAC.

100. Staff Captain CTD to DAG, 10 Oct 1916, RG9 III-B-1 v2938, LAC.

101. Steele to MacDougall, 30 Dec 1915, RG9 III-B-1 v622, LAC; Carson to MacDougall, 21 Jan 1916, 8-5-10c, RG9 III-A-1 v45, LAC.

102. MacDougall to Carson, 21 Jan 1916, 8-1-87a, RG9 III-A-1 v34, LAC.

103. Alderson to Carson, 29 Aug 1916, 8-5-8H, RG9 III-A-1 v44, LAC; Summary of General Conditions, LAC; Canadian Military School, Undated, S-7-36 v2, RG9 III-B-1 v3101, LAC; David Charles Gregory Campbell, “The Divisional Experience in the C.E.F.: A Social and Operational History of the 2nd Canadian Division, 1915-1918" (PhD diss., University of Calgary, 2003), 165.

104. Steele to MacDougall, 4 Sep 1916, 8-5-10f, RG9 III-A-1 v45, LAC.

105. 5th CIB Operations Report, Night of Sep 26/27 to Night of Oct 1/2, B.M.L. 330, 7 Oct 1916, MG30 E46 v2, Turner Fonds, LAC; 5th Brigade, B.M. 357, 30 Sep 1916, MG30 E46 v2, Turner Fonds, LAC.

106. For instance, the 3rd Division's 8th Brigade had an estimated strength of 1,625 men on 9 Oct even though it was out of the line during the attack. It should have had 4,000 men. 3rd Division, G.834, 9 Oct 1916, 17/3, RG9 III-C-3 v4679, LAC.

107. 1st Division GS War Diary, G10.213, 16 Oct 1916, RG9 III-D-3 v4829, LAC.

108. For instance, see Steele Diary, 29 Jan, 6 Feb 1916, BPSC; Steele to MacDougall, 4 Sep 1916, LAC.

109. Steele Diary, 8 Feb 1916, BPSC.

110. Ibid., 5 Feb 1916.

111. For example, see Steele to Carson, 25 Jul 1916, 8-5-10e, RG9 III-A-1 v45, LAC; Carson to Steele, 17 Jul 1916, 8-5-10e, RG9 III-A-1 v45, LAC; MacDougall to Carson, 23 Jun 1916, 8-5-10e, RG9 III-A-1 v45, LAC; Carson to Currie, 14 Dec 1915, 8-5-10b, RG9 III-A-1 v45, LAC.

112. Currie to Carson, 21 Jan 1916, 8-5-10c, RG9 III-A-1 v45, LAC.

113. French to Perley, 28 Aug 1917, 10-8-18, RG9 III-A-1 v73, LAC.

114. Steele Diary, 3, 8 Feb 1916, BPSC.

115. William F. Stewart, “'Byng Boys': A Profile of Senior Commanders of Canadian Combat Units on the Somme 1916," War in History 23, no. 1 (2016): 64. The remainder were British Regular Army officers or other categories.

116. Ibid., 78.

117. Steele Diary, 25 Mar, 1 Oct 1916, BPSC.

118. Morton, A Peculiar Kind of Politics, 42.

119. Steele Diary, 25 Sep 1916, BPSC.

120. Ibid., 22 Mar 1916.

121. For more on the changes, see Stewart, Embattled General, Chapter 6.

122. Steele to Perley, 18 Nov 1916, RG9 III-A-1 v74, LAC.

123. Examples include Steele Diary, 3 Feb, 13 May, 27 May 1916, BPSC; Narrative in Regard to Major-General Sir S.B. Steele, 3 Jan 1918, LAC. 
124. Steele Diary, 18 Dec 1916, BPSC.

125. Cable Perley to Borden, Undated, v7/3, MG27 II D12 v4-7, Perley Fonds, LAC.

126. Perley to Borden, 28 Jun 1917, LAC.

127. Training was conducted at the company level by instructors. Companies formed battalions, with multiple battalions in a training brigade, which reported to the CTD and it reported to Steele, hence the four levels.

128. See for example, Cdn HQ Shoreham from O.C. Cdn Engineer Training Depot, 11 Sep 1917, RG9 III-B-1 v3083, LAC.

129. Quoted in Sanders Marble Paul Harris, "British Military Thought and Operational Method on the Western Front, 1915-1917," War in History 15, no. 1 (2008): 34.

130. Steele Diary, 1 Jun 1916, BPSC.

Source Abbreviations

BPSC: Bruce Peel Special Collections, University of Alberta

LAC: Library and Archives, Canada 